\title{
Prostaglandin F2 $\alpha$ or estradiol benzoate to induce ovulation in timed artificially inseminated dairy cows
}

\author{
Luiz Francisco Machado Pfeifer(1), Luiz Gustavo Bruno Siqueira ${ }^{(2)}$, Eduardo Kenji Nunes Arashiro(2), \\ Natália Ávila de Castro $^{(3)}$ and João Henrique Moreira Viana ${ }^{(2)}$
}

\begin{abstract}
(1)Embrapa Rondônia, Rodovia BR-364, Km 5,5, s/non, Zona Rural, CEP 76815-800 Porto Velho, RO, Brazil. E-mail: luiz.pfeifer@embrapa.br (2)Embrapa Gado de Leite, Rua Eugênio do Nascimento, no 610, Bairro D. Bosco, CEP 36038-330 Juiz de Fora, MG, Brazil. E-mail: luiz.siqueira@embrapa.br, eduardoarashiro@hotmail.com, henrique.viana@embrapa.br ${ }^{(3)}$ Universidade Federal de Pelotas, Campus Universitário, s/no, CEP 960100-900 Capão do Leão, RS, Brazil. E-mail: nataliavetufpel@gmail.com
\end{abstract}

Abstract - The objective of this work was to compare two types of ovulation inducers - estradiol benzoate (EB group) or prostaglandin F2 $\alpha$ (PG group) -, in postpartum dairy cows subjected to timed artificial insemination (TAI). Lactating Holstein-Gir crossbred cows $(n=118)$ with 60 to 120 days of milk production were used in this study. All cows were treated with an intravaginal progesterone-releasing device (CIDR) plus $2 \mathrm{mg}$ of estradiol benzoate (EB) on day 0 . The CIDR inserts were removed on day 9, and all cows received $500 \mu \mathrm{g}$ sodium cloprostenol. Twenty-four hours after CIDR removal, cows were randomly assigned into two treatment groups and were given either $1 \mathrm{mg}$ of EB i.m. (EB group) or $500 \mu \mathrm{g}$ sodium cloprostenol i.m. (PG group). TAI were performed at 52 to 54 hours, in both EB and PG groups, after CIDR removal. No differences were observed in the ovulation $(85.2 \%$ vs $72.7 \%)$ and pregnancy rates $(40.7 \%$ vs $38.2 \%)$ between the EB and PG groups, respectively. Fertility is similar in the TAI protocols that use prostaglandin F2 $\alpha$ or EB to induce ovulation in lactating dairy cows.

Index terms: artificial insemination, cattle, estrus, synchronization, withdrawal period.

\section{Prostaglandina F2 $\alpha$ ou benzoato de estradiol para induzir a ovulação em vacas leiteiras inseminadas em tempo fixo}

\begin{abstract}
Resumo - O objetivo deste trabalho foi comparar dois indutores de ovulação - benzoato de estradiol (grupo BE) ou prostaglandina F2 $\alpha$ (grupo PG) -, em vacas leiteiras pós-parto submetidas à inseminação artificial em tempo fixo (IATF). Neste estudo, utilizaram-se vacas Girolando lactantes (n=118) com 60 a 120 dias em lactação. Todas as vacas foram tratadas com um implante intravaginal liberador de progesterona (CIDR) associado a $2 \mathrm{mg}$ de benzoato de estradiol (BE) no dia 0 . O CIDR foi retirado no dia 9 , e todas as vacas receberam $500 \mu \mathrm{g}$ i.m. de cloprostenol sódico (análogo à prostaglandina $\mathrm{F} 2 \alpha$ ). Vinte e quatro horas após a remoção do CIDR, as vacas foram aleatoriamente separadas em dois grupos, que receberam $1 \mathrm{mg}$ de BE i.m. (grupo BE) ou $500 \mu \mathrm{g}$ de cloprostenol sódico i.m. (grupo PG). As IATF foram realizadas de 52 a 54 horas, em ambos os grupos, após a remoção do CIDR. Não se observaram diferenças nas taxas de ovulação $(85,2$ vs. $72,7 \%)$ e de prenhez (40,7 vs. $38,2 \%$ ) entre os grupos BE e PG, respectivamente. A fertilidade é semelhante em protocolos de IATF que utilizam prostaglandina $\mathrm{F} 2 \alpha$ ou BE para induzir a ovulação em vacas leiteiras em lactação.
\end{abstract}

Termos para indexação: inseminação artificial, bovinos, estro, sincronização, período de carência.

\section{Introduction}

Poor reproductive performance in dairy cows continues to be an important issue in the dairy industry (Lucy, 2001; Walsh et al., 2011). However, the intensive use of timed artificial insemination (TAI) protocols, observed in commercial herds in the last two decades, has apparently stabilized the fertility in high-yielding dairy cows. Recently, considerable research efforts have focused on developing efficient strategies to induce synchronized ovulation for TAI in dairy cattle (Pereira et al., 2013). The advent of protocols for ovulation synchronization, which enables artificial insemination at a pre-established time with adequate fertility, has become an important component of breeding management in multiple production systems (Bisinotto et al., 2014). By controlling both luteal and follicular function by exogenous treatments, it is possible to synchronize the time of ovulation and, therefore, perform artificial insemination (AI) without the need for estrus detection (Bó et al., 2002). 
The typical TAI protocol involves the use of an intravaginal progesterone insert to mimic the luteal phase, estradiol benzoate (EB) to synchronize follicular wave emergence, prostaglandin F2 $\alpha$ analogues (PGF) to induce luteolysis, and an ovulation inducer that could be either an ester of estradiol (benzoate or cypionate) or a $\mathrm{GnRH}$ analogue, such as, gonadorelin and buserelin acetate (Kim et al., 2007; Souza et al., 2009; Bisinotto et al., 2014).

In addition to the well established role in causing luteolysis, PGF has been implicated to enhance fertility in cattle (Weems et al., 2006). The mechanism by which PGF may affect fertility, when it is used in TAI protocols, could act either by anticipating luteolysis (Bisinotto et al., 2010; Santos et al., 2010; Lima et al., 2013), or by improving uterine environment for early conception development (Neglia et al., 2008; Gabriel et al., 2011; Garcia-Ispierto \& Lópes-Gatius, 2014; Ambrose et al., 2015). Furthermore, incomplete luteolysis has been reported as a negative factor that impairs fertility of a TAI protocol (Santos et al., 2010). More recently, PGF alone given 24 hours after removal of the progesterone device has successfully induced ovulation in beef cattle undergoing TAI (Pfeifer et al., 2014). Also, previous studies used PGF to induce first ovulation in prepubertal heifers (Pfeifer et al., 2009; Leonardi et al., 2012). However, whether there is a direct action of exogenous PGF on ovulation remains controversial.

Treatment with PGF concurrent with AI could increase pregnancy rates by increasing uterine contractility(Stolla\& Schmid, 1990), thereby enhancing sperm transport (Garcia-Ispierto \& Lópes-Gatius, 2014; Ambrose et al., 2015), inducing the luteinizing hormone $(\mathrm{LH})$ release via a luteolysis-independent mechanism (Randel et al., 1996), and therefore, assisting the ovulatory process or hastening the luteal regression (Ambrose et al., 2015). Although the effects PGF given 24 hours after the progesterone device removal on hastening luteolysis has been studied (Bisinotto et al., 2010; Santos et al., 2010; Lima et al., 2013; Garcia-Ispierto \& Lópes-Gatius, 2014), to our knowledge, no study was performed to investigate whether PGF can induce ovulation by itself in TAI protocols for dairy cows. From a commercial perspective, the major significance of such studies is the possibility of developing a new method to induce ovulation in dairy cattle, reducing the use of estradiol in TAI protocols. It is noteworthy that, unlike estradiol, PGF does not have a withdrawal period (Food Animal Residue Avoidance Databank, 2016; National Office of Animal Health, 2016). Depending on the formula and the pharmaceutical laboratory, an ester of estradiol may have a withdrawal period of up to 30 days for milk and meat. Furthermore, since 2008, the European Community has banned the use of estradiol-17 $\beta$ in farm animals, after the Committee on Veterinary Measures Relating Science to Public Health labeled this compound as a complete carcinogen (Regal et al., 2011).

The objective of this work was to compare two types of ovulation inducers - estradiol benzoate (EB group) or prostaglandin $\mathrm{F}_{2} \alpha$ (PG group) - in postpartum dairy cows subjected to timed artificial insemination.

\section{Materials and Methods}

All animal procedures were carried out under Embrapa Ethics in the Use of Animals Committee approval number F.02/2014.

The experiment was performed using the facilities at Embrapa Gado de Leite Research Farm, located in Coronel Pacheco, MG, Brazil. Lactating Holstein-Gir crossbred cows $(n=118)$ were used in this work. Cows were 60 to 120 days of milk production (DIM) and had a body weight of 500 to $600 \mathrm{~kg}$, and a body condition score (BCS) ranging from 2.5 to 3 (range 1 to 5; $1=$ emaciated, 5 = obese).

The animals were maintained on pasture overnight, and fed a supplemental corn silage and grain ration during the day with ad libitum access to a mineral mixture, salt, and water. Cows were fed twice daily, and the diet was formulated to meet or exceed the nutritional requirements for lactating cows producing $25 \mathrm{~kg}$ of milk per day with $3.5 \%$ fat and $3.2 \%$ protein. Cows were milked twice daily at 12 -hour intervals. Before the beginning of the experiment, cows were examined twice, 11 days apart, using transrectal ultrasonography (US) and a $5 \mathrm{MHz}$ linear-array transducer (Esaote MyLab30 Vet Gold; Pie Medical-Esaote, Genoa, Italy) to confirm cyclicity [the presence of a corpus luteum (CL) in one or both US sessions]. Only cyclic cattle were included in this work.

All cows were treated with an intravaginal progesterone-releasing device (1.9 g progesterone, CIDR, Pfizer Animal Health, São Paulo, SP, Brazil) 
plus $2 \mathrm{mg}$ i.m. of estradiol benzoate (EB, Benzoato HC, Hertape Calier, Juatuba, MG, Brazil) on day 0. The CIDR inserts were removed on day 9, and all cows received $500 \mu \mathrm{g}$ i.m. of sodium cloprostenol (PGF2 $\alpha$-analogue, Ciosin, MSD Saúde Animal, São Paulo, SP, Brazil). Twenty-four hours after CIDR removal, cows were blocked according to number of lactation, age, milk production, BCS, and diameter of the dominant follicle, and within each block, they were allocated randomly to receive $1 \mathrm{mg}$ of EB i.m. (EB group, $\mathrm{n}=54), 500 \mu \mathrm{g}$ of sodium cloprostenol i.m. (PG group, $\mathrm{n}=55$ ) or $2 \mathrm{~mL}$ of $\mathrm{NaCl}$ at $0.9 \%$ (control group, $\mathrm{n}=9$ ). Timed artificial inseminations were performed 52 to 54 hours after CIDR removal in only EB and PG groups (Pfeifer et al., 2014). A single inseminator performed all TAI, and commercial semen straws from a bull with proven fertility were used.

On day 9, a subset of 28 cows from treatment groups $(\mathrm{EB}, \mathrm{n}=9$; $\mathrm{PG}, \mathrm{n}=10$; or control $(\mathrm{CTL}, \mathrm{n}=9)$ were examined by transrectal ultrasonography every 6 hours from CIDR removal up to 144 hours or until the detection of ovulation. The diameter and location of the follicles and CL were recorded as described by Pierson \& Ginther (1984). Cows were considered as having a fully developed pre-ovulatory follicle, when a follicle $\geq 12 \mathrm{~mm}$ was detected 1 day before TAI (Santos Filho et al., 2001). Blood flow of the largest (presumptive ovulatory) follicle was also evaluated using colour Doppler ultrasonography (Esaote MyLab30 Vet Gold; Pie Medical-Esaote, Genova, Italy) as previously described (Viana et al., 2013). The colour Doppler signals present in the follicular wall were subjectively scored on a 1 to 5 scale (1, no or very little blood flow; and 5, intense blood flow detected in most of the follicular walls) adapted from Ginther (2007). The colour Doppler evaluations were performed retrospectively using videos recorded at each examination. Ovulation was defined as the disappearance of a large follicle $(>10 \mathrm{~mm})$ that was previously identified as the pre-ovulatory dominant follicle.

All cows were examined by ultrasonography, for the following procedures: 24 hours after CIDR removal, to determine the diameter of the ovulatory follicle; on day 13 , to determine the occurrence of ovulation; and 30 days post-TAI, to detect pregnancy. Visualization of the embryonic vesicle and detection of the embryo heartbeat were the positive criteria for determining pregnancy.

All statistical analyses were performed using the SAS 9.0 software (SAS Institute Inc., Cary, NC, USA). The statistical model of the single-point outcome variables (i.e., maximum diameter of the ovulatory follicle and interval to ovulation) included the effect of treatment, body weight, age, BCS, lactation number, and postpartum days. The body weight, age, BCS, lactation number, and postpartum days did not have a significant effect on the model, and therefore, they were excluded from the final statistical model. Treatment was kept into the final model in all analyses. Therefore, in the final statistical model, single-point outcome variables were analyzed using one-way analysis of variance, and the means were compared among groups using Tukey's post hoc test. Bartlett's test of homogeneity of variance was used to compare variability of intervals from CIDR removal to ovulation among groups. Binary responses (percentage of cows that had a pre-ovulatory follicle, ovulation, pregnancy, and conception rates) were evaluated by chi-square analysis. The pregnancy rate was calculated as the proportion of pregnant cows 30 days after TAI, divided by the number of cows that were inseminated (P/AI). Similarly, the conception rate was calculated as the proportion of cows that were pregnant 30 days after TAI, divided by the number of cows that ovulated. Differences among groups were considered statistically significant, based on a $5 \%$ p-value. p-values $>5 \%$, but $<10 \%$ were considered to tend towards significance, as already done in animal reproduction experiments (Lima et al., 2013; Sá Filho et al., 2010).

\section{Results and Discussion}

The interval from CIDR removal to ovulation did not differ between groups (Table 1 and Figure 1). Ovulation ranges from CIDR removal were 66 to 78, 66 to 120, and 66 to 144 hours for EB, PG, and CTL groups, respectively (Table 1 ). One cow was discharged from the subset of the PG group due to the lack of regression of the previous CL, as confirmed by colour Doppler, and the remaining nine cows ovulated within 6 days after CIDR removal. All cows from the control group ovulated, and two cows from the subset of the EB group failed to ovulate within this time frame. The lack of difference in the time to ovulation 
among the different ovulation inducers, observed in the subsets of each group, was, however, not expected. Although cows treated with EB and PGF ovulated $\sim 20$ hours and $\sim 8$ hours earlier than the controls, respectively (Table 1), the reduced number of animals used for daily, every 6-hour ultrasound evaluations did not provide sufficient statistical power to detect differences in this outcome variable. In a previous study performed with Girolando heifers, PGF induced ovulation $\sim 73$ hours after CIDR removal (Pfeifer et al., 2014) which is in contrast with the current results on the PG group (84 hours).

In all subset groups, the follicular vascularization score progressively increased $(\mathrm{p}<0.001)$ until ovulation, and there was no differences in the follicle blood flow score 6 hours before ovulation within the groups $(4.0 \pm 0.5,3.4 \pm 0.5$, and $3.6 \pm 0.5$ for the control, $P G$, and $\mathrm{BE}$ groups, respectively $(\mathrm{p}>0.05)$. There was a negative correlation $(\mathrm{R}=-0.73 ; \mathrm{p}<0.02)$ between the follicle blood flow score immediately before treatment and the time to ovulation in the $\mathrm{PG}$ group but this did not occur in the other groups $(p=0.5)$. The direct effect of PGF on the inflammatory-like events that lead to ovulation are partially supported by the association between follicle vascularization and the time to ovulation, which was observed in the PG group, but not in the other ones, in the current work. This led us to further hypothesize that PGF, acting mainly by a local mechanism, requires a higher developmental status of pre-ovulatory follicles compared to the systemic-mediated action

Table 1. Fertility responses of dairy cows treated with estradiol benzoate (EB), prostaglandin $\mathrm{F} 2 \alpha(\mathrm{PG})$, or control group treated with $\mathrm{NaCl}$ (CTL), at the end of the TAI protocol.

\begin{tabular}{|c|c|c|c|c|}
\hline \multirow[t]{2}{*}{ Endpoint } & \multicolumn{3}{|c|}{ Ovulation inducer } & \multirow[t]{2}{*}{ p-value } \\
\hline & EB & PG & CTL & \\
\hline Interval to ovulation (hour) ${ }^{(1)}$ & $71.1 \pm 1.6$ & $84.0 \pm 5.6$ & $92.7 \pm 9.9$ & 0.14 \\
\hline Ovulatory follicle $\varnothing(\mathrm{mm})^{(2)}$ & $13.5 \pm 0.44$ & $13.8 \pm 0.46$ & NA & 0.67 \\
\hline Cows having a POF at TAI $(\%)^{(2)}$ & 72.2 & 80 & NA & 0.34 \\
\hline Ovulation rate $(\%)^{(2)}$ & 85.2 & 72.7 & NA & 0.11 \\
\hline Conception rate $(\%)^{(2)}$ & 47.8 & 52.5 & NA & 0.66 \\
\hline Pregnancy rate $(\%)^{(2)}$ & 40.7 & 38.2 & NA & 0.78 \\
\hline
\end{tabular}

(1)Calculation based on the subset evaluations ( $\mathrm{n}=9$ per group); hours from CIDR removal. ${ }^{(2)}$ Calculation based on the total number of cows subjected to TAI ( $\mathrm{n}=109)$. Control group (CTL) received an injection of $2 \mathrm{~mL}$ of $\mathrm{NaCl}$ $(0.9 \%) 24$ hours after CIDR removal, and cows were not inseminated. $\varnothing$, diameter; POF, pre-ovulatory follicle; TAI, timed artificial insemination; NA, not available. of EB. Therefore, the lower ovulatory synchrony observed in the PG group, in comparison to the EB group (Table 1), may be explained by the presence of less developed follicles, which was indicated by the observed low blood flow, regardless of size, which could be less responsive to PGF. Although injectable PGF has been shown to induce ovulation (Leonardi et al., 2012), its mechanism of action still needs to be clarified. A previous report showed an increased frequency of LH release, 6 hours after treatment with a PGF analogue, in anestrous cows (Randel et al., 1996). None of the follicles ovulated with a blood flow score smaller than 3, and the vascularization score of the largest follicles of the three cows from subgroup that failed to ovulate remained below 2 , during all of the evaluated periods.

Pregnancy and conception rates were not different between EB and PG groups (Table 1). Although a previous study also showed the ability of PGF to induce ovulation in TAI protocols for beef cattle (Pfeifer et al., 2014), to the best of our knowledge this is the first report to determine that PGF has a similar action in dairy cows subjected to TAI, using EB-progesterone-based protocols. In contrast, PGF

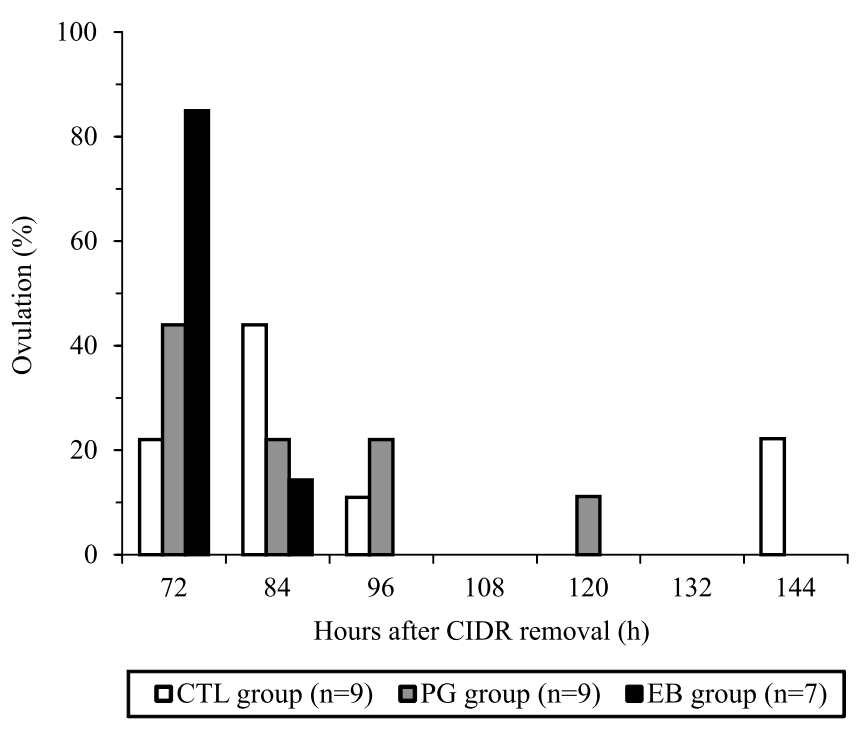

Figure 1. The percentage of dairy cows ovulating after CIDR removal, and the distribution of ovulation by time in the EB (estradiol), PG (prostaglandin), and control groups (CTL). Control group (CTL) received an injection of $2 \mathrm{~mL}$ $\mathrm{NaCl}(0.9 \%) 24$ hours after CIDR, removal and cows were not inseminated.

Pesq. agropec. bras., Brasília, v.51, n.6, p.738-744, jun. 2016 DOI: 10.1590/S0100-204X2016000600005 
given 24 hours after CIDR removal in 5d-GnRH-based protocols has provided controversial results. Two doses of PGF in the 5d TAI protocols improved luteolysis and pregnancy rates in dairy cows (Bisinotto et al., 2010; Santos et al., 2010), and heifers (Lima et al., 2013). However, Garcia-Ispierto \& Lópes-Gatius (2014) did not observe similar beneficial effects on dairy cows. On the other hand, all of these previous reports used GnRH to induce ovulation 32-48 hours after PGF. Therefore, and most importantly, the present work showed that, if used alone 24 hours after CIDR removal, PGF offers pregnancy rates that are similar to those of cows treated with EB.

Based only on the results of the subsets in the current work, one could speculate that as cows in the CTL group did not have a different ovulation pattern, in comparison to those of the EB and PG groups, untreated cows could also achieve similar pregnancy rates. However, based on the results of a previous study (Martinez et al., 2005) and on the foundational nature of the current work, we were not encouraged to risk using TAI in a large number of cows without treating them with an ovulation inducer. Considering that 55 to $65 \%$ of the cows are still not pregnant after the first postpartum AI (Bisinotto et al., 2010), the substitution of EB by PGF as the ovulation inducer in a TAI protocol provided satisfactory fertility in dairy cows $(\sim 40 \%)$. The acceptable pregnancy rates, obtained in both EB and PG groups (Table 1), is an evidence that ovulation probably occurred in a synchronous manner in both groups. This is a noteworthy achievement, particularly because the current results are similar to those reported in a previous study that used EB and ECP to induce ovulation in dairy cows (Pereira et al., 2013).

When cows were treated with estradiol benzoate to induce wave emergence and a progesterone insert for 8 days, without an ovulation inducer, ovulation occurred $\sim 96$ hours after $\mathrm{P}_{4}$ removal (Martinez et al., 2005), which is similar to that observed in the CTL group in the present work (Table 1). Souza et al. (2009) evaluated the effect of GnRH and ECP as ovulation inducers in lactating dairy cows. Ovulation occurred $\sim 74$ hours after $\mathrm{P}_{4}$ withdrawal, which is similar to the EB group in the current study; however, the rate of pregnancy per $\mathrm{AI}$ was $\sim 30 \%$, which is lower than that observed here $\sim 40 \%$ (Table 1 ).

Overall, the present study provides important initial data on the use of PGF as an ovulation inducer for TAI protocols in dairy cows. Hence, PGF may have a great potential for being used as an alternative compound to induce ovulation in dairy cows, particularly replacing estradiol. Although the TAI protocol used in this study did not completely remove estradiol, the second EB injection was abolished without decreasing fertility, resulting in a reduction of milk withdrawal, which could be cost-effective for the farmer (Pfeifer et al., 2014).

\section{Conclusions}

1. The fertility of lactating dairy cows subjected to timed artificial insemination (TAI) protocols that used prostaglandin F2 $\alpha$ analogues or estradiol benzoate as an ovulation inducer is similar.

2. The prostaglandin F2 $\alpha$ injection induces ovulation in a synchronized manner in dairy cows, and could be successfully used as an ovulation inducer in a TAI protocol.

\section{Acknowledgements}

To Coordenação de Aperfeiçoamento de Pessoal de Nível Superior (Capes) and to Empresa Brasileira de Pesquisa Agropecuária (Embrapa, Project MP2 n. ${ }^{\circ}$ 02.12.01.021.00.00), for financial support.

\section{References}

AMBROSE, D.J.; GOBIKRUSHANTH, M.; ZUIDHOF, S.; KASTELIC, J.P. Low-dose natural prostaglandin F2 $\alpha$ (dinoprost) at timed insemination improves conception rate in dairy cattle. Theriogenology, v.83, p.529-534, 2015. DOI: 10.1016/j. theriogenology.2014.10.034.

BISINOTTO, R.S.; RIBEIRO, E.S.; MARTINS, L.T.; MARSOLA, R.S.; GRECO, L.F.; FAVORETO, M.G.; RISCO, C.A.; THATCHER, W.W.; SANTOS, J.E.P. Effect of interval between induction of ovulation and artificial insemination (AI) and supplemental progesterone for resynchronization on fertility of dairy cows subjected to a 5-d timed AI program. Journal of Dairy Science, v.93, p.5798-5808, 2010. DOI: 10.3168/jds.2010-3516.

BISINOTTO, R.S.; RIBEIRO, E.S.; SANTOS, J.E.P. Synchronisation of ovulation for management of reproduction in dairy cows. Animal, v.8, p.151-159, 2014. Suppl. s1. DOI: $10.1017 / \mathrm{S} 1751731114000858$.

BÓ, G.A.; BARUSELLI, P.S.; MORENO, D.; CUTAIA, L.; CACCIA, M.; TRÍBULO, R.; TRÍBULO, H.; MAPLETOFT, R.J. The control of follicular wave development for self-appointed embryo transfer programs in cattle. Theriogenology, v.57, p.53-72, 2002. DOI: 10.1016/S0093-691X(01)00657-4. 
FOOD ANIMAL RESIDUE AVOIDANCE DATABANK. Food Animal Residue Avoidance Databank: a component of the Food Animal Residue Avoidance \& Depletion Program. Available at: $<$ http://www.farad.org>. Accessed on: Mar. 162016.

GABRIEL, H.G.; WALLENHORST, S.; DIETRICH, E.; HOLTZ, W. The effect of prostaglandin $F 2_{\alpha}$ administration at the time of insemination on the pregnancy rate of dairy cows. Animal Reproduction Science, v.123, p.1-4, 2011. DOI: 10.1016/j. anireprosci.2010.11.010.

GARCIA-ISPIERTO, I.; LÓPES-GATIUS, F. Effects of different five-day progesterone-based fixed-time AI protocols on follicular/luteal dynamics and fertility in dairy cows. Journal of Reproduction and Development, v.60, p.426-432, 2014. DOI: 10.1262/jrd.2014-063.

GINTHER, O.J. Follicle blood flow. In: GINTHER, O.J. Ultrasonic imaging and animal reproduction: color-Doppler ultrasonography. Cross Plains: Equiservices, 2007. Chapter 5, p.87-114.

KIM, U.-H.; SUH, G.-H.; HUR, T.-Y.; KANG, S.-J.; KANG, H.-G.; PARK, S.-B.; KIM, H.-S.; KIM, I.-H. Comparison of two types of CIDR-based timed artificial insemination protocols for repeat breeder dairy cows. Journal of Reproduction and Development, v.53, p.639-645, 2007. DOI: 10.1262/jrd.18147.

LEONARDI, C.E.P.; PFEIFER, L.F.M.; RUBIN, M.I.B.; SINGH, J.; MAPLETOFT, R.J.; PESSOA, G.A.; BAINY, A.M.; SILVA, C.A.M. Prostaglandin F2 $\alpha$ promotes ovulation in prepubertal heifers. Theriogenology, v.78, p.1578-1582, 2012. DOI: 10.1016/j. theriogenology.2012.06.030.

LIMA, F.S.; RIBEIRO, E.S.; BISINOTTO, R.S.; GRECO, L.F.; MARTINEZ, N.; AMSTALDEN, M.; THATCHER, W.W.; SANTOS, J.E.P. Hormonal manipulations in the 5-day timed artificial insemination protocol to optimize estrous cycle synchrony and fertility in dairy heifers. Journal of Dairy Science, v.96, p.7054-7065, 2013. DOI: 10.3168/jds.2013-7093.

LUCY, M.C. Reproductive loss in high-producing dairy cattle: Where will it end? Journal of Dairy Science, v.84, p.1277-1293, 2001. DOI: 10.3168/jds.S0022-0302(01)70158-0.

MARTINEZ, M.F.; KASTELIC, J.P.; BO, G.A.; CACCIA, M.; MAPLETOFT, R.J. Effects of oestradiol and some of its esters on gonadotrophin release and ovarian follicular dynamics in CIDR-treated beef cattle. Animal Reproduction Science, v.86, p.37-52, 2005. DOI: 10.1016/j.anireprosci.2004.06.005.

NATIONAL OFFICE OF ANIMAL HEALTH. National Office of Animal Health. Available at: <http://www.noahcompendium. co.uk>. Accessed on: Mar. 162016.

NEGLIA, G.; NATALE, A.; ESPOSITO, G.; SALZILLO, F.; ADINOLFI, L.; CAMPANILE, G.; FRANCILLO, M.; ZICARELLI, L. Effect of prostaglandin F2 $\alpha$ at the time of AI on progesterone levels and pregnancy rate in synchronized Italian Mediterranean buffaloes. Theriogenology, v.69, p.953-960, 2008. DOI: 10.1016/j.theriogenology.2008.01.008.

PEREIRA, M.H.C; SANCHES, C.P.; GUIDA, T.G.; RODRIGUES, A.D.P.; ARAGON, F.L.; VERAS, M.B.; BORGES, P.T.; WILTBANK, M.C.; VASCONCELOS, J.L.M. Timing of prostaglandin $\mathrm{F} 2 \alpha$ treatment in an estrogen-based protocol for timed artificial insemination or timed embryo transfer in lactating dairy cows. Journal of Dairy Science, v.96, p.2837-2846, 2013. DOI: $10.3168 /$ jds.2012-5840.

PFEIFER, L.F.M.; LEONARDI, C.E.P.; CASTRO, N.A.; VIANA, J.H.M.; SIQUEIRA, L.G.B.; CASTILHO, E.M.; SINGH, J.; KRUSSER, R.H.; RUBIN, M.I.B. The use of PGF2 $\alpha$ as ovulatory stimulus for timed artificial insemination in cattle. Theriogenology, v.81, p.689-695, 2014. DOI: 10.1016/j.theriogenology.2013.11.016.

PFEIFER, L.F.M.; SIQUEIRA, L.G.; MAPLETOFT, R.J.; KASTELIC, J.P.; ADAMS, G.P.; COLAZO, M.G.; SINGH, J. Effects of exogenous progesterone and cloprostenol on ovarian follicular development and first ovulation in prepubertal heifers. Theriogenology, v.72, p.1054-1064, 2009. DOI: 10.1016/j. theriogenology.2009.06.022.

PIERSON, R.A.; GINTHER, O.J. Ultrasonography of the bovine ovary. Theriogenology, v.21, p.495-504, 1984. DOI: 10.1016/0093-691X(84)90411-4.

RANDEL, R.D.; LAMMOGLIA, M.A.; LEWIS, A.W.; NEUENDORFF, D.A.; GUTHRIE, M.J. Exogenous PGF2 $\alpha$ enhanced GnRH-induced LH release in postpartum cows. Theriogenology, v.45, p.643-654, 1996. DOI: 10.1016/0093-691X(95)00410-A.

REGAL, P.; NEBOT, C.; DÍAZ-BAO, M.; BARREIRO, R.; CEPEDA, A.; FENTE, C. Disturbance in sex-steroid serum profiles of cattle in response to exogenous estradiol: a screening approach to detect forbidden treatments. Steroids, v.76, p.365-375, 2011. DOI: 10.1016/j.steroids.2010.12.005.

SÁ FILHO, M.F.; CRESPILHO, A.M.; SANTOS, J.E.P.; PERRY, G.A.; BARUSELLI, P.S. Ovarian follicle diameter at timed insemination and estrous response influence likelihood of ovulation and pregnancy after estrous synchronization with progesterone or progestin-based protocols in suckled Bos indicus cows. Animal Reproduction Science, v.120, p.23-30, 2010. DOI: 10.1016/j. anireprosci.2010.03.007.

SANTOS, J.E.P.; NARCISO, C.D.; RIVERA, F.; THATCHER, W.W.; CHEBEL, R.C. Effect of reducing the period of follicle dominance in a timed artificial insemination protocol on reproduction of dairy cows. Journal of Dairy Science, v.93, p.2976-2988, 2010. DOI: 10.3168/jds.2009-2870.

SANTOS FILHO, A.S.; OLIVEIRA, M.A.L.; CALDAS, J.G.L.; LIMA, P.F.; DONATO, I.V. Ovarian follicular dynamics of five-eighths Girolando cows. Reproduction in Domestic Animals, v.36, p.207-210, 2001. DOI: 10.1046/j.1439-0531.2001.d01-39.x.

SOUZA, A.H.; VIECHNIESKI, S.; LIMA, F.A.; SILVA, F.F.; ARAÚJO, R.; BÓ, G.A.; WILTBANK, M.C.; BARUSELLI, P.S. Effects of equine chorionic gonadotropin and type of ovulatory stimulus in a timed-AI protocol on reproductive responses in dairy cows. Theriogenology, v.72, p.10-21, 2009. DOI: 10.1016/j. theriogenology.2008.12.025.

STOLLA, R.; SCHMID, G. Auswirkungen natürlicher und synthetischer PGF2 $\alpha$-Präparate auf die Uteruskontraktilität des Rindes. Berliner und Münchener Tierärztliche Wochenschrift, v.103, p.198-202, 1990.

VIANA, J.H.M.; ARASHIRO, E.K.N.; SIQUEIRA, L.G.B.; GHETTI, A.M.; AREAS, V.S.; GUIMARÃES, C.R.B.; PALHAO, 
M.P.; CAMARGO, L.S.A.; FERNANDES, C.A.C. Doppler ultrasonography as a tool for ovarian management. Animal Reproduction, v.10, p.215-222, 2013.

WALSH, S.W.; WILLIAMS, E.J.; EVANS, A.C.O. A review of the causes of poor fertility in high milk producing dairy cows. Animal
Reproduction Science, v.123, p.127-138, 2011. DOI: 10.1016/j. anireprosci.2010.12.001.

WEEMS, C.W.; WEEMS, Y.S.; RANDEL, R.D. Prostaglandins and reproduction in female farm animals. The Veterinary Journal, v.171, p.206-228, 2006. DOI: 10.1016/j.tvj1.2004.11.014.

Received on July 15, 2015 and accepted on March 30, 2016 